\title{
Ciliostasis of airway epithelial cells facilitates influenza A virus infection
}

\author{
Yuguang Fu ${ }^{1,2+}$, Jie Tong ${ }^{1 \dagger}$, Fandan Meng ${ }^{1}$, Doris Hoeltig ${ }^{3}$, Guangliang Liu², Xiangping Yin ${ }^{2}$ \\ and Georg Herrler ${ }^{1 *}$ (D)
}

\begin{abstract}
Porcine precision-cut lung slices (PCLS) were used to analyze the effect of the ciliary activity on infection of airway epithelial cells by influenza viruses. Treatment of slices with $2 \% \mathrm{NaCl}$ for 30 min resulted in reversible ciliostasis. When PCLS were infected by a swine influenza virus of the H3N2 subtype under ciliostatic conditions, the viral yield was about twofold or threefold higher at 24 or $48 \mathrm{~h}$ post-infection, respectively, as compared to slices with ciliary activity. Therefore, the cilia beating not only transports the mucus out of the airways, it also impedes virus infection.
\end{abstract}

\section{Introduction, methods and results}

The high frequncy of respiratory infections [1] indicates that the respiratory tract is a portal of entry that is frequently used by pathogenic microorganisms to enter a mammalian host. The continuous uptake of air and the large surface area make the airway system vulnerable by environmental factors. To prevent the detrimental effect of harmful substances, the respiratory tract is equipped with a mucociliary clearance system which is based on the function of specialized epithelial cells [reviewed in 2, 3]. Mucins released from mucus-producing cells form a viscous mucus-layer that entraps foreign particles, including viruses and bacteria. The removal of the entrapped material is accomplished by another type of specialized cells that are equipped with cilia. The cilia are surrounded by a fluid of low viscosity that allows their coordinated movement. As a result of this ciliary activity, the mucus layer that is floating on top of the periciliary layer is transported out of the airway.

We were interested to know whether the protective effect of the mucociliary clearance system is solely dependent on the mucus layer or whether the ciliary activity itself-apart from its mucus transport

\footnotetext{
*Correspondence: Georg.Herrler@tiho-hannover.de

†Yuguang Fu and Jie Tong contributed equally to this work

${ }^{1}$ Institute of Virology, University of Veterinary Medicine Hannover,

Foundation, Hannover, Germany

Full list of author information is available at the end of the article
}

function-is also impeding infection by pathogens. For this purpose, we used swine influenza virus of the H3N2 subtype because of its superior growth properties in PCLS [4] to analyze the infection of differentiated respiratory epithelial cells by influenza virus in the absence and presence of ciliostatic conditions.

\section{Reversible ciliostasis in differentiated airway epithelial cells}

To analyze the effect of ciliostasis on virus infection, we chose precision-cut lung slices as a culture system for differentiated airway epithelial cells. They were prepared as reported previously $[5,6]$. Briefly, the cranial, middle, and intermediate lobes of fresh lungs of three-month-old clinically healthy pigs were obtained from the Clinics for Swine and Small Ruminants and Forensic Medicine and Ambulatory Service at the University of Veterinary Medicine, Foundation, Hannover, Germany. Prior to organ removal the pigs were euthanized by intravenous application of $80 \mathrm{mg} /$ kg pentobarbital (Euthadorm ${ }^{\circledR}$, Co. CP Pharma GmbH, Burgdorf, Germany). The lobes were filled with $37{ }^{\circ} \mathrm{C}$ warm low-melting agarose (AGAROSE LM; GERBU, Heidelberg, Germany). After solidification, cylindrical portions containing a bronchial airway were stamped out by using an $8-\mathrm{mm}$ tissue coring tool. Using the Krumdieck tissue slicer (TSE systems, model MD400001, Bad Homburg, Germany), slices of about $250 \mu \mathrm{m}$ thickness were generated. PCLS were transferred to 
24-well plates (one slice/well) and maintained in $1 \mathrm{~mL}$ of RPMI 1640 medium (Genaxxon, Germany) supplemented with antibiotics and antimycotics. Slices were monitored under the light microscope (Zeiss Axiovert 35) for ciliary activity. For experiments, only slices were chosen in which the ciliary activity was retained on the whole luminal surface of the airway visible under the microscope (designated as 100\% activity).

To induce ciliostasis, we applied hypertonic salt concentrations [7]. Porcine PCLS were treated with medium containing $\mathrm{NaCl}$ at the indicated concentrations. After incubation at $37^{\circ} \mathrm{C}$ for the times indicated, the hypertonic medium was replaced by fresh medium immediately. As shown in Figure 1, treatment of PCLS with any of the different hypertonic salt concentrations for 5 min resulted in complete ciliostasis. When slices were returned to physiological medium, ciliary activity was recovered to some extent depending on the salt concentration used to induce ciliostasis. Full recovery of the ciliary activity-i.e. the whole luminal surface visible under the microscope showed cilia beating-was observed only with slices treated with $2 \% \mathrm{NaCl}$. Therefore, the following experiments were performed under this experimental condition. Next we analyzed which time period of treatment with high salt was tolerated by the slices without affecting the recovery of the ciliary activity. As shown in Figure 2, when PCLS were treated with $2 \% \mathrm{NaCl}$ for 30,60 and $90 \mathrm{~min}$, ciliary activity was recovered to values of about $90 \%$ or somewhat higher. Recovery of the cilia beating on the whole luminal surface visible under the microscope was detected only when the salt treatment was as short as $30 \mathrm{~min}$. Therefore, a short adsorption period was chosen for the infection experiments described below.

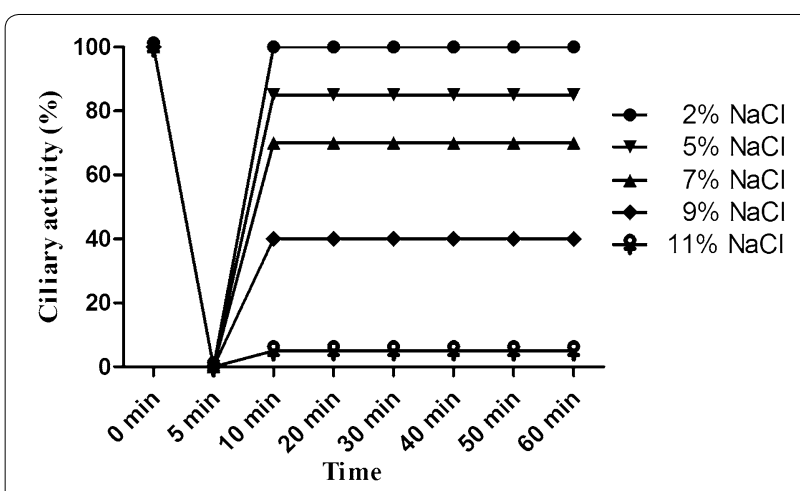

Figure 1 Effect of hypertonic $\mathrm{NaCl}$ on ciliary activity of PCLS.

PCLS were treated with sodium chloride at different concentrations. When cilia had stopped beating, the culture medium was replaced by fresh medium without hypertonic sodium chloride. PCLS were monitored under the microscope for ciliary activity.

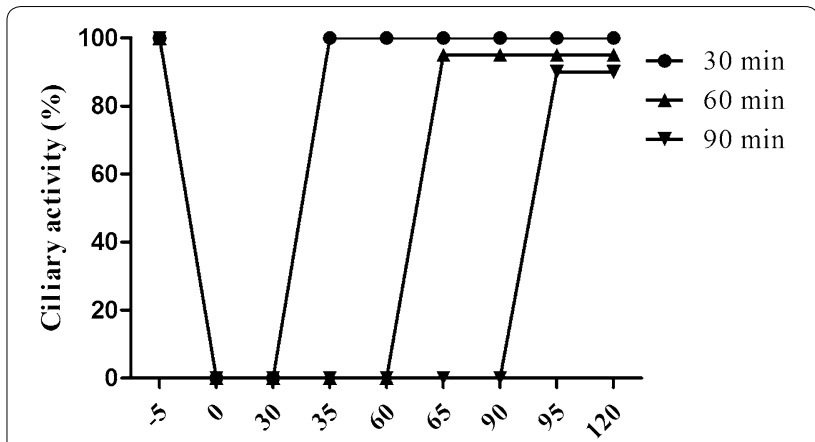

Time period (min) of treatment with $2 \% \mathrm{NaCl}$

Figure 2 The tolerance of PCLS under $\mathbf{2} \% \mathrm{NaCl}$ condition. PCLS were treated with $2 \% \mathrm{NaCl}$ for different time period. At the indicated times, medium containing $2 \% \mathrm{NaCl}$ was replaced by physiological medium. The ciliary activity was determined by microscopic inspection of the slices.

\section{Infection of PCLS under ciliostatic conditions}

Swine influenza virus of the H3N2 subtype (A/sw/ Herford/IDT5932/2007) was provided by Michaela Schmidtke, University of Jena, Germany. Virus was propagated in Madin-Darby canine kidney (MDCK) cells that were cultured with Eagle's minimal essential medium (EMEM) containing 10\% fetal bovine serum (Sigma, USA). Infected cells were incubated in EMEM supplemented with acetylated trypsin (Sigma-Aldrich, Munich) $1 \mu \mathrm{g} / \mathrm{mL}$. After $72 \mathrm{~h}$, the supernatant was harvested and, after removal of cell debris by centrifugation at $2000 \times g$ for $10 \mathrm{~min}$, virus was stored at $-80{ }^{\circ} \mathrm{C}$. Prior to infection of PCLS, we analyzed whether treatment with high salt affects the infectivity of influenza viruses. Virus was incubated with medium in the presence or absence of $2 \% \mathrm{NaCl}$ for $30 \mathrm{~min}$ and then subjected to a plaque assay with MDCK cells as described previously [8, 9]. Both preparations were found to have the same titer of infectious virus (not shown) indicating that the high salt treatment did not affect the infectivity of the influenza viruses.

Porcine PCLS were infected with the H3N2 subtype of swine influenza virus at an infectious dose of $10^{4}$ $\mathrm{TCID}_{50}$ per slice for $20 \mathrm{~min}$ in the presence or absence of $2 \% \mathrm{NaCl}$, i.e. in the presence or absence of the ciliary activity. Supernatants were collected at different time points post-infection and stored at $-80{ }^{\circ} \mathrm{C}$. Viral titers of samples were determined by endpoint dilution titration on MDCK cells as described previously [10]. As shown in Figure 3, at $24 \mathrm{hpi}$, the virus titer was about twofold higher when PCLS were infected under ciliostatic conditions compared to infection at physiological conditions. At $48 \mathrm{hpi}$, the difference was about threefold. This result indicates that infection of differentiated airway epithelial 


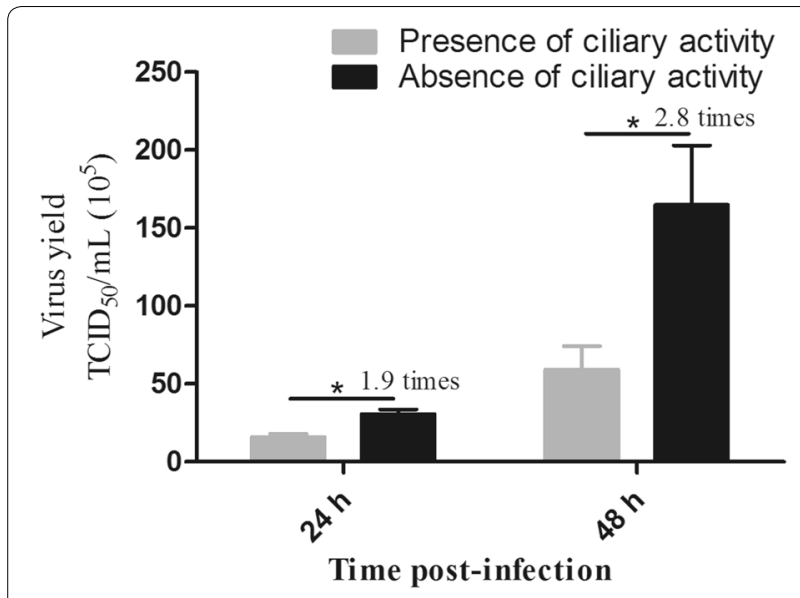

Figure 3 Effect of ciliostatic conditions on the infection of PCLS by influenza virus. PCLS were infected with $\mathrm{H} 3 \mathrm{~N} 2$ subtype of swine influenza virus at an infectious dose of $10^{4} \mathrm{TCID}_{50}$ per slice in the presence or absence of the ciliary activity during the attachment step. After removal of the inoculum, cells were incubated under physiological conditions. Supernatants were collected at 24 and 48 hpi and analyzed for infectivity by $\mathrm{TCID}_{50}$ assay.

cells by H3N2 influenza virus is more efficient in the absence of ciliary activity.

\section{Discussion}

The role of the ciliary activity in transporting mucus with entrapped foreign substances out of the airways is a wellrecognized feature of the mucociliary clearance system $[2,3]$. We have addressed the question whether the protective role of the cilia beating is restricted to the mucus transport function or whether it has an additional effect on infection e.g. by impeding the attachment process of viruses. Even in the absence of mucus, the constant movement of the cilia may affect the viruses when they try to get access to cell surface. Precision-cut lung slices are a convenient culture system to examine the importance of the ciliary activity, because the cilia beating can be easily monitored by microscopic inspection. In this way we could determine conditions for reversible ciliostasis that are applicable to influenza virus infections. We indeed found that infection of porcine PCLS by a swine influenza virus of the H3N2 subtype was facilitated under ciliostatic conditions. A two- or threefold increase in the virus yield may appear to be not very impressive. However, this difference will be increased when infection involves more replication cycles. The success of a pathogen to induce an infection not only depends on the ability to initiate an infection but also on the efficiency. In this respect, the ciliary activity may help to prevent a number of infections.
It should be noted that we chose a microorganism that is very efficient in the attachment to target cells. Binding of influenza viruses to sialic acid containing receptors is readily observed after incubation for $20 \mathrm{~min}$. Viruses or bacteria that attach to specific protein receptors are usually incubated with host cells for $2 \mathrm{~h}$ or more. It will be interesting to find out whether in such cases the impeding effect of the ciliary activity is increased.

For convenience, we chose hypertonic salt conditions to induce reversible ciliostasis. Influenza viruses were found not to be affected in their infectivity by high salt treatment. By contrast, Streptococcus suis stopped to amplify when treated with $2 \% \mathrm{NaCl}$. In such cases, one may use pharmacological substances to induce reversible ciliostasis $[11,12]$.

\section{Competing interests}

The authors declare that they have no competing interests.

\section{Authors' contributions}

GH, FM and DH designed the experiments; YF performed the experiments; DH contributed animal; YF, JT and GH analyzed the data; YF, FM, DH, GL, XY and $\mathrm{GH}$ wrote or helped to draft the paper. All authors read and approved the final manuscript.

\section{Acknowledgements}

This work was performed by YF in partial fulfillment of the requirements for doctoral degrees from the University of Veterinary Medicine Hannover. We are grateful to China Scholarship Council for providing fellowship for YF, and Michaela Schmidtke for providing H3N2 subtype of swine influenza virus.

\section{Author details}

${ }^{1}$ Institute of Virology, University of Veterinary Medicine Hannover, Foundation, Hannover, Germany. ${ }^{2}$ Lanzhou Veterinary Research Institute, State Key Laboratory of Veterinary Etiological Biology, Chinese Academy of Agricultural Sciences, Lanzhou, Gansu Province, China. ${ }^{3}$ Clinic of Swine and Small Ruminants and Forensic Medicine and Ambulatory Service, University of Veterinary Medicine Hannover, Foundation, Hannover, Germany.

\section{Consent for publication}

Not applicable.

\section{Ethics approval}

All pigs used for these experiments were crossbreeds and raised and kept in the Clinic for Swine and Small Ruminants and forensic Medicine and Ambulatory Service, University of Veterinary Medicine Hannover, Foundation. The pigs were raised and kept in accordance with the recommendations of the European Convention for the Protection of Vertebrate Animals used for Experimental and Other Scientific Purposes, European Treaty Series, nos. 123/170 $[13,14]$. Study design, including all measures, and housing of the animals were approved by a local, independent committee on ethics (Commission for ethical estimation of animal research studies of the Lower Saxonian State Office for Consumer Protection and Food Safety (approval number 33.9-42502-0509A627) and were in accordance with the requirements of the national animal welfare law. Compliance with animal welfare law and ethics were regularly controlled by the local authorities.

\section{Funding}

This work was supported by grants from the Deutsche Forschungsgemeinschaft (DFG) to GH (He1168/15-1; He1168/17-1; He1168/19-1).

\section{Publisher's Note}

Springer Nature remains neutral with regard to jurisdictional claims in published maps and institutional affiliations. 
Received: 6 April 2018 Accepted: 6 July 2018

Published online: 18 July 2018

\section{References}

1. Monto AS, Malosh RE, Petrie JG, Thompson MG, Ohmit SE (2014) Frequency of acute respiratory illnesses and circulation of respiratory viruses in households with children over 3 surveillance seasons. J Infect Dis 210:1792-1799

2. Ganesan S, Comstock AT, Sajjan US (2013) Barrier function of airway tract epithelium. Tissue Barriers 1:e24997

3. Tilley AE, Walters MS, Shaykhiev R, Crystal RG (2015) Cilia dysfunction in lung disease. Annu Rev Physiol 77:379-406

4. Meng F, Punyadarsaniya D, Uhlenbruck S, Hennig-Pauka I, SchwegmannWessels C, Ren X, Dürrwald R, Herrler G (2013) Replication characteristics of swine influenza viruses in precision-cut lung slices reflect the virulence properties of the viruses. Vet Res 44:110

5. Goris K, Uhlenbruck S, Schwegmann-Wessels C, Köhl W, Niedorf F, Stern M, Hewicker-Trautwein M, Bals R, Taylor G, Braun A, Bicker G, Kietzmann M, Herrler G (2009) Differential sensitivity of differentiated epithelial cells to respiratory viruses reveals different viral strategies of host infection. J Virol 83:1962-1968

6. Punyadarsaniya D, Liang $\mathrm{CH}$, Winter C, Petersen $\mathrm{H}$, Rautenschlein $\mathrm{S}$, Hennig-Pauka I, Schwegmann-Wessels C, Wu CY, Wong CH, Herrler G (2011) Infection of differentiated porcine airway epithelial cells by influenza virus: differential susceptibility to infection by porcine and avian viruses. PLoS One 6:e28429
7. Boek WM, Keleş N, Graamans K, Huizing EH (1999) Physiologic and hypertonic saline solutions impair ciliary activity in vitro. Laryngoscope 109:396-399

8. Vietmeier J, Niedorf F, Bäumer W, Martin C, Deegen E, Ohnesorge B, Kietzmann M (2007) Reactivity of equine airways: a study on precision cut lung slices. Vet Res Commun 31:611-619

9. Yang W, Punyadarsaniya D, Lambertz RL, Lee DC, Liang CH, Höper D, Leist SR, Hernández-Cáceres A, Stech J, Beer M, Wu CY, Wong CH, Schughart K, Meng F, Herrler G (2017) Mutations during the adaptation of H9N2 avian influenza virus to the respiratory epithelium of pigs enhance sialic acid binding activity and virulence in mice. J Virol 91:e02125

10. Van Rikxoort M, Michaelis M, Wolschek M, Muster T, Egorov A, Seipelt J, Doerr HW, Cinatl JJ (2012) Oncolytic effects of a novel influenza A virus expressing interleukin-15 from the ns reading frame. PLoS One 7:e36506

11. Boek WM, Romeijn SG, Graamans K, Verhoef JC, Merkus FW, Huizing EH (1999) Validation of animal experiments on ciliary function in vitro. I. The influence of substances used clinically. Acta Otolaryngol 119:93-97

12. Boek WM, Romeijn SG, Graamans K, Verhoef JC, Merkus FW, Huizing EH (1999) Validation of animal experiments on ciliary function in vitro. II. The influence of absorption enhancers, preservatives and physiologic saline. Acta Otolaryngol 119:98-101

13. European convention for the protection of vertebrate animals used for experimental and other scientific purposes. http://conventions.coe.int/ Treaty/en/Treaties/Html/123.htm. Accessed 01 Jan 1991

14. Protocol of amendment to the European convention for the protection of vertebrate animals used for experimental and other scientific purposes. http://conventions.coe.int/Treaty/en/Treaties/Html/170.htm. Accessed 02 Dec 2005
Ready to submit your research? Choose BMC and benefit from:

- fast, convenient online submission

- thorough peer review by experienced researchers in your field

- rapid publication on acceptance

- support for research data, including large and complex data types

- gold Open Access which fosters wider collaboration and increased citations

- maximum visibility for your research: over $100 \mathrm{M}$ website views per year

At BMC, research is always in progress.

Learn more biomedcentral.com/submissions 